\title{
Editorial
}

\section{Oversimplified Speculation on the Demise of Libraries}

"The wave of the future is coming and there is no fighting it."

\section{Anne Morrow Lindbergh}

A few years ago, prognosticators were saying that the digital movement would drive libraries out of business. Well, those who thought such was going to happen overnight must be terribly disappointed. Only a small percent of the world's informational resources have been digitized. Digital resources, however, are a wonderful complement to the print collections; they have improved access to information significantly and also have proved to be an asset in the preservation of the human record.

The latest phenomenon driving the predictions of soothsayers about the demise of libraries centers on the efforts of some vendors/companies to place a large collection of books online. If students can buy access to 250,000 titles of books placed online to support an undergraduate curriculum, why would one need a library? The issue of how well balanced the online collection is for support of the respective curriculum must not be forgotten.

\section{Having the Right Answers}

When a college library director is engaged in a budget discussion with the administrator responsible for the library, it should not be too far-fetched to expect a question such as: Because students can now buy online access to thousands of books, and based on the library's site licenses to access several hundred online journals, why do we need to continue spending an increasing amount of money year after year for paper collections? Or a

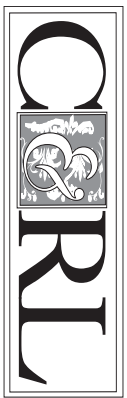
not-too-informed official may simply ask: Why do we need a paper-based collection any longer? If the library is chock full and a new building is necessary, be prepared to answer: Because everything is now online, why do we need a new library? Notwithstanding their naivete, these questions deserve correct, documented, compelling, and convincing answers. Commercials and advertisements have predicted that the complete Library of Congress will soon be available online. We must dispel these exaggerated and untruthful statements. And the people promoting them should be held legally responsible.

\section{Impact of Alternative Sources}

Access to online resources will continue to flourish, and its impact on traditional library services will be overwhelming. Community and four-year college libraries will be transformed more by the digital environment than the larger research university libraries will be. Some community college libraries have doubled their collection size by acquiring e-books. It will be several years before some of the books held by research universities appear in digital format. As more rare and special collections are digitized, there will be greater access to these once-somewhat-inaccessible treasures. In a sense, the once-great collections will be a bit less great owing to their online availability.

\section{Falling Figures}

In recent years, we have witnessed declining circulation figures in American academic libraries and likewise can be said for the number of reference transac- 
tions. As more students have the capacity to access via Internet enough resources from their homes and dorm rooms to complete their term papers, circulation and reference figures will fall even more. Students want convenience; if they can find enough resources via the Internet without coming to the library, why make the trip to the library? An unfortunate aspect to obtaining online resources for term papers and other library-related projects strictly via the Internet is that many times students cannot access the older materials; subsequently, they use what they can find online and ignore the historical, and in some instances more important, resources.

\section{Working with Faculty}

A key variable in the successful survival of the academic library hinges on an effective working relationship between librarians and teaching faculty. Faculty instigate most of the use of libraries by students, especially undergraduate students. Prior to the online environment, faculty, of course, knew far more than students about the paper-based collections in their respective disciplines. Now it is not surprising to learn that students know more about search engines for accessing and the availability of electronic resources. Librarians must become more active in educating faculty about how to find and properly use the online resources. We can no longer wait for faculty to come to us, but we must go to them.

\section{Research Opportunities}

The transformation of the traditional library to the electronic library offers many opportunities for research. In nearly every issue of College $\mathcal{E}$ Research Libraries published in the past five years, at least one article is related to the use of technology in academic libraries. This issue of CERL, for example, contains three articles on Web-based services.

Unquestionably, research is necessary to advance academic librarianship. Moreover, we need more emphasis on analyzing and synthesizing problems and issues to establish a theoretical foundation for our practices and services and to create a solid base on which we can "invent the future."

\section{Conclusion}

Simplified or not, speculation on the future of academic libraries will magnify as evolving technology becomes more sophisticated. My opinion is that the future for librarians is both bright and intriguing. We must establish our role on our respective campuses as the one group that best knows how to access, select, filter, and customize information for users. The day for our role as knowledge navigators has come. In a nutshell, a positive attitude, a strong service orientation, and expertise in both the paper-based and electronic environments, despite all the negative predictions, will result in an exciting and productive future. As Ruth Benedict stated, "Our faith in the present dies out long before our faith in the future."

DONALD E. RIGGS

Editor, College $\mathcal{E}$ Research Libraries 